\title{
ESTIMASI NILAI LINGKUNGAN PERKEBUNAN KELAPA SAWIT DITINJAU DARI NERACA AIR TANAMAN KELAPA SAWIT (STUDI KASUS: PERKEBUNAN KELAPA SAWIT DI KECAMATAN DAYUN, KABUPATEN SIAK, PROPINSI RIAU)
}

\author{
THE ESTIMATION OF OIL PALM PLANTATION ENVIRONMENTAL VALUE USING CROP \\ EVAPOTRANSPIRATION OF OIL PALM \\ (CASE STUDY: OIL PALM PLANTATION IN DAYUN SUBDISTRICT, SIAK REGENCY, \\ RIAU PROVINCE)
}

\author{
Isa Teguh Widodo ${ }^{1}$ dan Bambang Dwi Dasanto ${ }^{1}{ }^{*}$ \\ ${ }^{1}$ Bagian Klimatologi, Dept. Geofisika dan Meteorologi, FMIPA IPB \\ Kampus IPB Darmaga, Bogor, 16680 \\ *Corresponding author. E-mail: bambangdwi@ scientist.com
}

Penyerahan Naskah: 11 Januari 2010

Diterima untuk diterbitkan: 19 Mei 2010

\begin{abstract}
ABSTRAKS
Dayun area is one of the centers of oil palm plantation in Siak Regency. State-owned company that develops oil palm plantation in Dayun is PT Perkebunan Nusantara V (PTPN V) which is the first company developing oil palm plantation in Siak Regency. The oil palm plantations cause various effects to the environment; one of them is the decreasing water availability for the water stakeholders. The decreasing water availability causes additional cost to the community. The objectives of this study were to determine the decreasing of water availability which was caused by oil palm plantation, and its cost to meet the needs of water. The study used water balance model by Thornwhite 1957 and Willingness to Pays (WTP) analysis using questionaire of Contingent Valuation Method (CVM) in Sawit Permai, Dayun Subdistrict, Siak Regency. The land cover, before and after, affects the water balance which impacts the water availability in Dayun. The decreasing water availability was comparable with the increasing water demand in oil palm plantation, equal to $67 \mathrm{~mm} / \mathrm{year}$. Oil palm plantation had greater runoff than that of forest. The need of water in oil palm plantation in Dayun was 42.728 liters/ha/day, with the daily need of a single palm tree equal to $0,012 \mathrm{~m}^{3} / \mathrm{s}$. Based on the analysis of debt estimation, there is debt decreasing which indicates the decreasing water availability in Dayun, around $349 \mathrm{~m}^{3} / \mathrm{s}$ yearly. The estimated value of the environment for oil palm plantation by water resources consumption based on the difference of forest and oil palm plantation during the dry season (JJA) is equal to Rp 7.500.000. Average WTP for the water conservation program is $R p$ 26.400, with WTP maximum and minimum up to $R p 45.000$ and $R p 5.000$, respectively. The economic value of water conservation program is $R p 18.850 .000 /$ month.
\end{abstract}

Keywords: CVM, environment value, ETc, land use conversion, water balance, WTP

\section{PENDAHULUAN}

Tahun 2009 luas perkebunan kelapa sawit (oil palm plantation) di Kabupaten Siak sekitar 186.819 Ha (Dinas Kehutanan dan Perkebunan Kabupaten Siak 2009). Kecamatan Dayun merupakan sentral pertumbuhan dan perkembangan utama areal perkebunan kelapa sawit di Kabupaten Siak dengan persentase luas sekitar 11,7\% atau sekitar $21.949 \mathrm{Ha}$ (BPS Kab. Siak 2008). Laju perubahan penggunaan lahan di DAS Siak terjadi sangat signifikan terutama dengan semakin bertambah luasnya areal perkebunan kelapa sawit (Adi 2007). Kelapa sawit merupakan salah satu tanaman di dunia yang paling cepat meningkat (Fitzherbert et al 2008).

Tanaman kelapa sawit secara ekologis merupakan tanaman yang banyak membutuhkan air dalam proses pertumbuhannya. Dan tanaman ini dapat tumbuh dengan baik apabila air tanah tersedia secara cukup (curah hujan tahunan 2000-2500 mm) dan tanpa periode kering yang nyata (Henson et al 2005, Kallarackal et al 2004, Umana dan Chinchilla 1991 dalam Murtilaksono et al 2009). 
Perubahan penggunaan lahan hutan ke bukan hutan pada umumnya akan merubah sistem dan tatanan neraca air yang ada di wilayah tersebut. Dampak dari perubahan tersebut dapat positif ataupun negatif; untuk mengetahui implikasi dari hal ini perlu dihitung nilai kerugian lingkungannya. Nilai lingkungan perkebunan kelapa sawit dalam penelitian ini didekati sebagai nilai konsumsi sumberdaya air melalui perhitungan neraca air pada tanaman kelapa sawit. Selain itu penelitian ini juga menggunakan nilai WTP sebagai indikator kesanggupan masyarakat dalam mendukung program konservasi sumberdaya air.

Adapun tujuan dari penelitian ini adalah:

1. Menghitung serta menganalisis neraca air lahan antara sebelum dan sesudah ada perkebunan kelapa sawit

2. Menghitung kebutuhan air perkebunan kelapa sawit

3. Mengestimasi nilai ekonomi lingkungan tanaman kelapa sawit

4. Menganalisis WTP masyarakat untuk program konservasi sumberdaya air

\section{METODE PENELITIAN}

\section{Data}

Data yang digunakan dalam kajian ini berupa data primer dan sekunder. Data primer merupakan hasil wawancara atau interview terhadap responden yang tinggal di sekitar perkebunan kelapa sawit di Desa Sawit Permai, Kecamatan Dayun dengan alat sadap berupa kuesioner. Data sekunder meliputi data klimatologi (curah hujan dan suhu), tanah dan statistik kependudukan yang diperoleh dari instansi yang berwenang.

\section{Analisis Neraca Air Neraca Air Umum}

Analisis neraca air umum Thornwhite dan Matter (1957) dilakukan untuk melihat sebaran potensi hujan rata-rata bulanan. Metode ini menggunakan data klimatologis dan bermanfaat untuk mengetahui kejadian bulan basah dan bulan kering. Data iklim yang dibutuhkan dalam metode ini adalah data suhu dan curah hujan bulanan ratarata dalam rentang waktu 30 tahun (1979-2009).

\section{Neraca Air Lahan}

Model ini merupakan penggabungan data klimatologis dengan data jenis tanah terutama data kadar air pada Kapasitas Lapang (KL), kadar air tanah pada Titik Layu Permanen (TLP), dan Air tersedia (WHC = Water Holding Capacity). Kapasitas lapang adalah keadaan tanah yang cukup lembab yang menunjukan jumlah air terbanyak yang dapat ditahan oleh tanah terhadap gaya tarik grafitasi. Air yang dapat ditahan tanah tersebut akan terus menerus diserap akar tanaman atau menguap sehingga tanah makin lama makin kering. Pada saat itu akar tanaman tidak lagi mampu menyerap air sehingga tanaman menjadi layu. Titik layu permanen adalah kondisi kadar air tanah yang akar-akar tanaman tidak mampu lagi menyerap air tanah, sehingga tanaman layu. Data yang diperoleh dari PTPN V untuk KL di wilayah penelitian adalah sebesar $200 \mathrm{~mm}$, sedangkan TLP adalah sebesar 80 $\mathrm{mm}$, dengan jenis tanahnya adalah Podsolik Merah Kekuningan (PMK) atau menurut klasifikasi USDA berjenis Ultisol. Air tersedia adalah jumlah air tersedia yang mampu digunakan oleh tanaman, yang merupakan selisih antara KL dan TLP.

\section{Neraca Air Tanaman}

Model ini merupakan penggabungan data klimatologis, data tanah, dan data jenis tutupan lahan yang ada. Data tanaman yang digunakan adalah data koefisien tanaman $(\mathrm{kc})$. Tanaman tutupan lahan (landcover) dibagi menjadi dua bagian, yaitu sebelum dan sesudah ada perkebunan kelapa sawit. Asumsi yang digunakan dalam penelitian ini adalah untuk landcover sebelum ada perkebunan kelapa sawit berupa hutan primer sedangkan landcover sesudah ada perkebunan kelapa sawit berupa tanaman kelapa sawit dan tidak ada tanaman lain yang tumbuh pada lahan perkebunan kelapa sawit tersebut. Asumsi berikutnya adalah faktor intersepsi tajuk oleh pohon kelapa sawit tidak dimasukkan dalam perhitungan kebutuhan air serta kejadian limpasan yang terjadi. Kebutuhan air dan limpasan dihitung berdasarkan persamaan empiris yang digunakan dalam penelitian ini.

Model neraca air yang dikembangkan oleh Thornwhite menggunakan sistem tata buku dengan kaidah analisisnya sebagai berikut:

1. Data Suhu (T)

Suhu yang digunakan dalam analis neraca air ini berupa data suhu bulanan rata-rata selama 30 tahun, yaitu periode 1979-2009.

2. Indeks Panas (I)

Data indeks panas disesuaikan berdasarkan data suhu bulanan yang mengacu pada tabel indeks panas yang terdapat pada buku Thornwhite.

3. ETP belum disesuaikan (ETP Unadj)

Perhitungan ETP Unadj mengacu pada tabel indeks panas berdasarkan data suhu udara yang ada. Tabel ETP Unadj mengacu pada buku Thornwhite.

4. ETP disesuaikan (ETP $a d j)$

Langkah ini dibagi kedalam dua bagian:

a. Mencari Faktor Koreksi 
Faktor koreksi merupakan nilai tetapan yang diperoleh berdasarkan informasi nilai lintang wilayah kajian.

b. Menetapkan ETP disesuaikan (ETP adj). ETP adj diperoleh dengan cara mengalikan nilai ETP Unadj dengan faktor koreksi.

5. Curah Hujan $(\mathrm{CH})$

Data curah hujan yang digunakan merupakan data curah hujan bulanan selama 30 tahun dengan peluang terlampaui $70 \%$. Periode hujan yang digunakan adalah curah hujan bulanan tahun 1979-2009. Persamaan yang digunakan untuk menghitung peluang hujan terlampaui $70 \%$ adalah :

$$
\mathrm{P}(70 \%)=C H \text { rataan }-(0,53 * S D C H)
$$

6. CH-ETP adj

Langkah ini adalah langkah mengurangkan nilai $\mathrm{CH}$ bulan tertentu dengan nilai ETP adj pada bulan tersebut.

7. Kehilangan Air Potensial Terakumulasi $(A P W L)$ Langkah ini adalah mengisi data $C H$-ETP adj yang bernilai negatif dan diakumulasikan sampai bertemu dengan data $C H$-ETP adj yang bernilai positif.

8. KAT atau WHC

Langkah ini adalah memasukan data KL dan TLP dari jenis tanah yang ada. Nilai KAT didapat dengan menggunakan rumus:

$$
K A T=K L \exp { }^{(A P W L / K L)}
$$

9. $\triangle \mathrm{KAT}$ (Perubahan Kadar Air Tanah)

$\triangle$ KAT merupakan selisih kandungan air tanah antara satu periode dengan periode sebelumnya secara berurutan. Nilai $\Delta$ KAT yang positif menunjukkan kejadian penambahan kandungan air tanah. Penambahan ini akan terhenti setelah KL tercapai.

10. ETA (Evapotranspirasi Aktual) Mengisi kolom ETA dengan catatan sebagai berikut:

Apabila $\mathrm{CH}>\mathrm{ETP}$,

maka ETA = ETP.......

Apabila $\mathrm{CH}<\mathrm{ETP}$,

maka $E T A=C H+\triangle K A T$.

Pada kondisi $\mathrm{CH}<\mathrm{ETP}$, maka tanah akan mulai mengering dan ETA menjadi lebih rendah dari nilai evapotranspirasi potensialna (ETP).

11. Defisit

Mengisi kolom defisit dengan menghitung selisih antara ETP dengan ETA. Defisit berarti pengurangan air untuk keperluan evapotranspirasi potensial. Nilai defisit merupakan jumlah air yang perlu ditambahkan untuk memenuhi keperluan ETP tanaman.

12. Surplus

Mengisi kolom surplus dengan menggunakan persamaan berikut:

$$
\mathrm{S}=\mathrm{CH}-\mathrm{ETP}-\Delta \mathrm{KAT}
$$

Surplus merupakan suatu keadaan air mencapai kapasitas lapang pada saat terjadi kelebihan curah hujan.

13. Run off (Limpasan)

Run off menunjukan besarnya air yang mengalir dipermukaan tanah. Cara perhitungannya menggunakan persamaan berikut:

Rol(Januari $)=50 \% \times$ S1, Ro2 (Februari $)=$ $50 \% \times 50 \% \quad x \quad$ S1(Januari) $+50 \% \quad x \quad S 2$

(Februari), dan seterusnya sampai pada Rol2 (Desember).

\section{Kebutuhan Air Tanaman Kelapa Sawit}

Menurut Doorenbos dan Pruitt (1976), kebutuhan air suatu tanaman merupakan jumlah atau tinggi air yang dibutuhkan untuk mengimbangi kehilangan air melalui proses evapotranspirasi tanaman dan ini dinyatakan sebagai:

$$
E T c=k c \times E T P
$$

Berdasarkan penelitian Harahap dan Darmosarkoro (1994) nilai crop coefisien (kc) untuk tanaman kelapa sawit berkisar antara 0,82 (untuk LAI< 2) sampai 0,93 (untuk LAI> 5). Kelapa sawit di wilayah studi berada pada kelompok umur $>7$ tahun dan ini memiliki nilai LAI berkisar antara 4,9-5,1. Oleh karena itu, nilai crop coefisien yang digunakan adalah 0,93 .

\section{Estimasi Debit (Q)}

Estimasi debit diselesaikan dengan metode Mock (1973) dan bentuk persamaanya adalah t:

$$
\begin{aligned}
& Q=\frac{\frac{R o}{1000} \times C A}{86400 \times N} \\
& R o=B f+D R O \\
& B f=I x V n \\
& V n=[0.5 \times(1+k) \times I] \\
& I=S x i
\end{aligned}
$$

$\mathrm{I}=$ infiltrasi, $\mathrm{S}=$ surplus, $\mathrm{i}=$ koefisien infiltrasi, $\mathrm{Vn}$ = simpanan air tanah, $\mathrm{Bf}=$ merupakan aliran dasar, Ro = aliran permukaan/limpasan, $\mathrm{Q}=$ estimasi debit $\left(\mathrm{m}^{3} / \mathrm{s}\right), \mathrm{CA}=$ luas DAS $\left(\mathrm{m}^{2}\right)$, dan $\mathrm{N}=$ jumlah hari dalam satu bulan. 


\section{Estimasi Nilai Ekonomi Lingkungan Perkebunan Kelapa Sawit}

Estimasi nilai lingkungan perkebunan kelapa sawit didekati dengan menghitung jumlah yang dibutuhkan oleh tanaman kelapa sawit dalam satu hektar lahan perkebunan. Adapun persamaan yang digunakan adalah sebagai berikut:

\section{Nilai Lingkungan $=($ ETc Sawit - ETc Hutan $) x$ Harga Air x Luas Lahan \\ Nilai Ekonomi $=$ Pendapatan rata-rata per hektar per bulan $\times 12$}

Nilai Lingkungan dan Nilai Ekonomi dihitung dalam satuan rupiah (Rp). Hasil perbandingan antara nilai ekonomi dan nilai lingkungan kemudian digunakan untuk mengestimasi apakah perkebunan kelapa sawit memberikan keuntungan atau memberikan kerugian berdasarkan jumlah kebutuhani air yang digunakan dalam perkebunan ini. Alat analisis yang digunakan adalah CVM (contingen valuation method) yang berupa kuisioner yang langsung ditujukan kepada setiap individu/masyarakat yang tinggal di sekitar perkebunan kelapa sawit. Dalam metode ini, kuisioner didesain sampai kepada taraf perbaikan lingkungan melalui program konservasi sumberdaya air. Analisis yang digunakan adalah WTP (Wilingness To Pays). WTP merupakan kemampuan atau kesediaan membayar dari setiap individu untuk mendapatkan perbaikan kualitas lingkungan akibat ekstraksi sumberdaya. Langkah-langkah analisis yang digunakan untuk menilai program konservasi sumberdaya air adalah sebagai berikut:

1. Menetapkan harga bayangan kerusakan lingkungan

2. Menentukan nilai rata-rata WTP

3. Menetapkan Bid Curve

4. Mengagregatkan data

\section{HASIL DAN PEMBAHASAN}

\section{Gambaran Umum Lokasi Penelitian}

Kecamatan Dayun merupakan pemekaran dari Kecamatan Siak dan merupakan tempat pertama untuk pengembangan perkebunan kelapa sawit di Kabupaten Siak oleh PT Perkebunan Nusantara V. Secara geografis wilayah Kecamatan Dayun terletak pada posisi $1^{\circ} 18^{\prime} 21^{\prime \prime} \mathrm{LU}-0^{\circ} 14^{\prime} 49^{\prime}$ 'LU dan $105^{\circ} 50^{\prime} 20^{\prime \prime}$ BT $-102^{\circ} 10^{\prime} 59^{\prime}$ 'BT.

Jumlah penduduk Kecamatan Dayun, pada tahun 2008 berjumlah 24.266 jiwa. Topografi tempat bermukim penduduk di wilayah ini sebagian besar berupa dataran rendah di bagian Timur dan dataran tinggi di sebelah Barat. Elevasinya berkisar antara 1$103 \mathrm{~m}$ dpl. Pada umumnya struktur tanah terdiri dari tanah podsolik merah kuning, organosol dan gley humus di rawa-rawa atau tanah basah. Berdasarkan status curah hujan, topografi, dan tanah ini maka Kecamatan Dayun sangat cocok untuk pengembangan perkebunan kelapa sawit. Namun, untuk wilayah yang berawa atau basah dalam upaya pemanfaatannya perlu masukan teknologi (diadaptasi dari Nasrul et al 2008).

\section{Analisis Neraca Air \\ Neraca air umum}

Hasil ploting data hujan, wilayah ini senantiasa basah setiap bulannya dan menurut klasifikasi iklim Koppen masuk kedalam tipe iklim Af dengan curah hujan tahunan $1989 \mathrm{~mm} / \mathrm{tahun}$. Pola hujan yang terjadi di Kecamatan Dayun termasuk kedalam kategori equatorial dengan puncak hujan terjadi pada bulan April dan November, dan curah hujan minimum terjadi pada bulan Juni (Gambar 1).

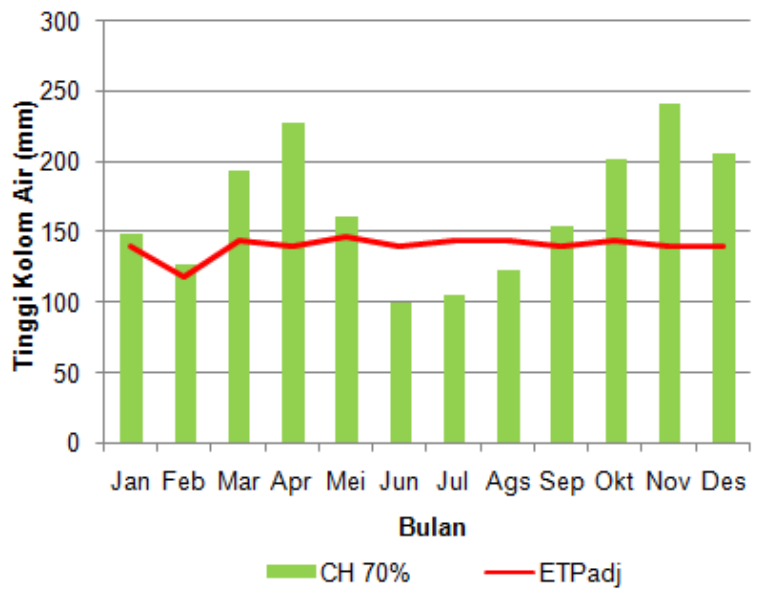

Gambar 1 Hasil Perhitungan Neraca Air Umum Kecamatan Dayun.

Pada bulan JJA (Juni, Juli, Agustus), curah hujan yang terjadi lebih kecil dibandingkan dengan bulan-bulan lainnya, artinya rentang waktu ini merupakan musim kemarau, sedangkan musim hujan terjadi pada bulan Oktober-April. Nilai ETPadj (evapotranspirasi terkoreksi) berdasarkan Gambar 1 adalah sebesar $1677 \mathrm{~mm} /$ tahun. Nilai ETPadj dalam setiap bulannya hampir sama, kecuali pada bulan Februari nilai ETPadj yang terjadi lebih kecil dibandingkan dengan ETPadj pada bulan-bulan lainnya.

\section{Neraca Air Lahan}

Pada analisis ini telah digunakan faktor KL dan TLP dari jenis tanah yang ada, dan hasilnya lihat Gambar 2. Berdasarkan Gambar 2 hujan yang turun pada bulan Juni, Juli, dan Agustus lebih kecil dibandingkan dengan nilai ETPadj yang terjadi. Kondisi ini mengakibatkan defisit pada lahan, karena curah hujan yang terjadi mengakibatkan 
perbedaan antara ETPadj dengan evapotranspirasi aktual (ETA). Berdasarkan hasil analisis yang dilakukan, defisit air pada ke tiga bulan tersebut secara kumulatif mencapai $22 \mathrm{~mm}$. Dengan demikian, bulan JJA termasuk dalam kategori musim kemarau untuk wilayah Kecamatan Dayun. Surplus kumulatif dari bulan-bulan selain bulan JJA dalam setahun adalah $412 \mathrm{~mm}$. Apabila wilayah ini dirancang untuk tanaman pertanian, maka pada bulan JJA memerlukan pasokan air tambahan untuk memenuhi kebutuhan air pada saat terjadi defisit air, seperti irigasi. Namun apabila wilayah ini dirancang untuk perkebunan, maka perlu memperhatikan faktor solum (kedalaman perakaran) dari jenis tanaman yang akan dikembangkan. Secara umum, kedalamn perakaran untuk tanaman perkebunan adalah sebesar $60 \mathrm{~cm}$. Pada bulan JJA, curah hujan yang turun lebih kecil dibandingkan dengan nilai KL yang ada. Namun, curah hujan yang terjadi pada ketiga bulan tersebut masih berada di atas nilai TLP dari jenis tanah yang ada sehingga masih mampu mencukupi kebutuhan evapotranspirasi baik potensial maupun aktual, sehingga nilai kadar air tanah dan water holding capacity tidak akan mengalami gangguan.

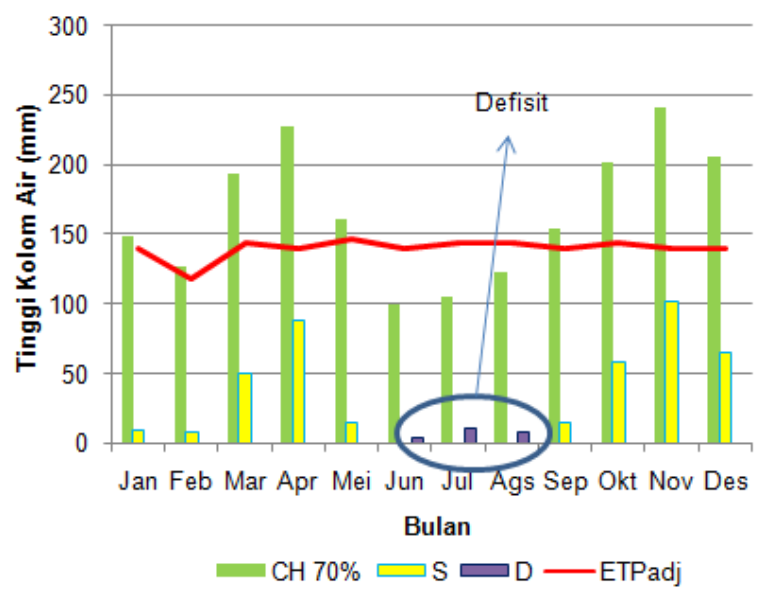

Gambar 2 Hasil Perhitungan Neraca Air Lahan Kecamatan Dayun.

\section{Neraca air tanaman}

Neraca air tanaman merupakan salah satu pendekatan untuk menentukan jumlah kebutuhan air suatu tanaman. Kebutuhan air suatu tanaman dapat dihitung berdasarkan jumlah air yang dievapotranspirasikan oleh tanaman itu sendiri (crop evapotranspiration, ETc). Setiap tanaman memiliki koefisien tanaman (crop coeficien) yang akan mempengaruhi nilai ETc yang terjadi. Pada penelitian ini, tutupan lahan awal adalah hutan alami dan saat sekarang berupa perkebunan kelapa sawit.

Nilai kc rata-rata untuk jenis hutan adalah 0,870,89 (Shuttleworth 1988, dalam Van der Wert 1994), sedangkan untuk tanaman kelapa sawit adalah sebesar 0,93 untuk tanaman kelapa sawit yang berumur lebih dari 7 tahun (Harahap 1999). Berdasarkan hasil analisis yang dilakukan, nilai ETc untuk tanaman kelapa sawit adalah $1560 \mathrm{~mm} / \mathrm{tahun}$, sedangkan ETc untuk hutan adalah $1492 \mathrm{~mm} /$ tahun. Perubahan tutupan lahan ini mengakibatkan adaanya peningkatan kebutuhan air tanaman sebesar 67 $\mathrm{mm} / \mathrm{tahun}$, dan akan mempengaruhi ketersediaan air yang ada pada lahan tersebut.

Perbedaan landcover antara sebelum ada perkebunan kelapa sawit (Gambar 3) dan sesudah ada perkebunan kelapa sawit (Gambar 4) menyebabkan penurunan nilai surplus air yang ada pada lahan tersebut.

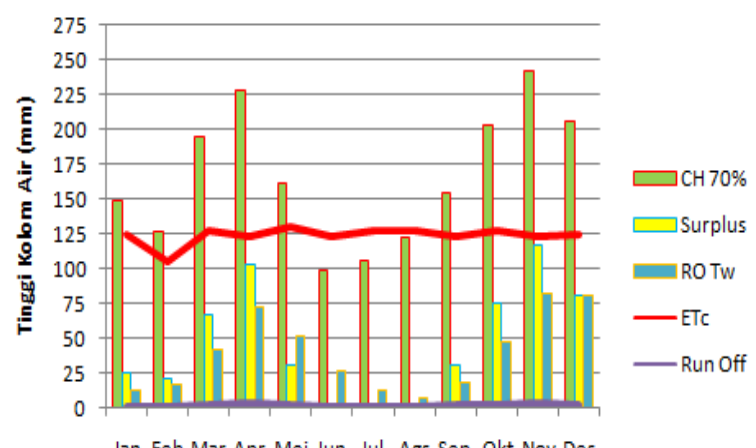

Bulan

Gambar 3 Neraca Air Tanaman sebelum ada perkebunan kelapa sawit.

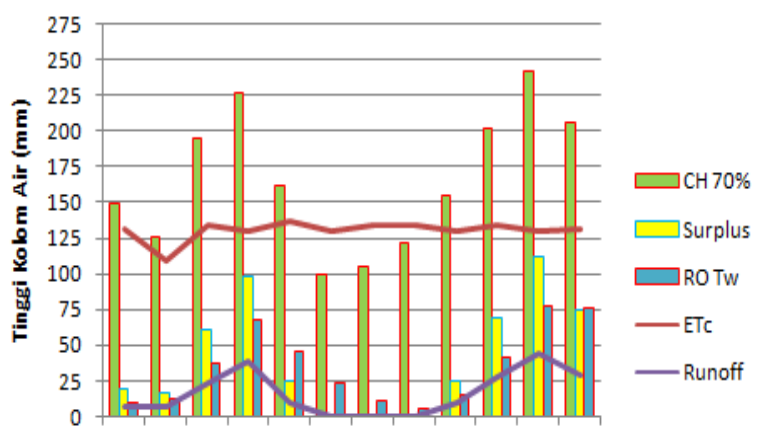

Jan Feb Mar Apr Mei Jun Jul Ags Sep Okt Nov Des

Bulan

Gambar 4 Neraca Air Tanaman sesudah ada perkebunan kelapa sawit.

Penurunan surplus ini sekitar $50 \mathrm{~mm}$ per tahun, dan ini akan mempengaruhi debit yang terjadi. Debit sebelum ada perkebunan kelapa sawit adalah sebesar $2708 \mathrm{~m}^{3} / \mathrm{s}$ dan sesudah ada perkebunan kelapa sawit adalah sebesar $2359 \mathrm{~m}^{3} / \mathrm{s}$ atau mengalami penurunan. Penurunan debit berarti pengurangan nilai air tersedia yang mampu dimanfaatkan oleh berbagai stakeholder pengguna air, dan salah satunya adalah sektor domestik.

Pengaruh lain dari alih fungsi lahan dari hutan menjadi tanaman perkebunan monokultur seperti perkebunan kelapa sawit adalah peningkatan nilai run off (limpasan permukaan). Berdasarkan Gambar 
3 dan Gambar 4, dapat dilihat bahwa nilai run off untuk landcover perkebunan kelapa sawit lebih besar dibandingkan dengan run off untuk landcover hutan. Nilai run off untuk landcover hutan adalah 16 $\mathrm{mm}$, sedangkan run off untuk landcover perkebunan kelapa sawit $200 \mathrm{~mm}$. Artinya landcover hutan mampu menahan air limpasan pada saat terjadi hujan dan menyimpan air lebih banyak sehingga mampu dimanfaatkan untuk sektor kebutuhan air lainnya. Namun, fungsi ini akan berubah pada saat terjadi konversi lahan hutan ke tanaman monukultur seperti perkebunan kelapa sawit. Secara umum, perbandingan kondisi hidrologi suatu wilayah dengan ada hutan dan tanpa ada hutan adalah sebagai berikut:

- Terjadi peningkatan erosi dan sedimentasi

- Peningkatan volume limpasan

- Peningkatan intensitas banjir dan kemarau

Kondisi ini sejalan dengan paparan Menteri Pekerjaan Umum pada Seminar Pelestarian dan Penyelamatan DAS Siak Tahun 2007 yang terdapat fluktuasi debit yang besar antara musim hujan dan kemarau (Qmaks: $1.700 \mathrm{~m}^{3} /$ detik, Qmin: 45 $\mathrm{m}^{3} /$ detik, Qmaks/Qmin: 37,8). Angka ini menjelaskan pada saat musim hujan, jumlah air yang ada akan berlebihan dan menyebabkan kejadian banjir. Namun, pada saat musim kemarau tiba, jumlah air yang ada akan sangat kurang dan berada di bawah batas lestari sungai. Oleh karena itu, hutan sangat berperan penting dalam menjaga tata air pada sistem neraca air pada suatu lahan.

\section{Kebutuhan Air Tanaman Kelapa Sawit}

Hasil analisis neraca air tanaman kelapa sawit menjelaskan bahwa dalam setahun, kebutuhan air rata-rata perkebunan kelapa sawit mencapai nilai $1560 \mathrm{~mm} / \mathrm{tahun}$. Jika luas perkebunan kelapa sawit di Kecamatan Dayun mencapai 21.949 Ha maka total kebutuhan air untuk perkebunan kelapa sawit di Kecamatan Dayun mencapai 42.728 liter/ha/hari. Kebutuhan air ini diperkirakan akan semakin meningkat, seiring dengan peningkatan jumlah penduduk dan luasan areal perkebunan kelapa sawit di wilayah ini. Dalam satu hektar lahan perkebunan kelapa sawit, berdasarkan data yang diperoleh dari PTPN V, jumlah batang pohon kelapa sawit sebanyak 143 batang atau pokok. Dengan jumlah ini, maka dapat diestimasikan jumlah kebutuhan air untuk satu pohon kelapa sawit dalam sehari mencapai $0,012 \mathrm{~m}^{3} / \mathrm{s}$ per hari.

\section{Estimasi Debit (Q)}

Model neraca air lahan yang dikembangkan oleh Thornwhite hanya mampu mengestimasi neraca air sampai pada taraf run off yang terjadi pada suatu lahan. Untuk menghitung jumlah debit yang terjadi digunakan pendekatan yang di kembangkan oleh
Mock (1973). Menurut Hariadi (2006) potensi ketersediaan air di wilayah Kabupaten Siak dengan luas DAS sekitar $2050 \mathrm{~km}^{2}$ antara sebelum dan sesudah ada perkebunan kelapa sawit mengalami penurunan (Gambar 5).

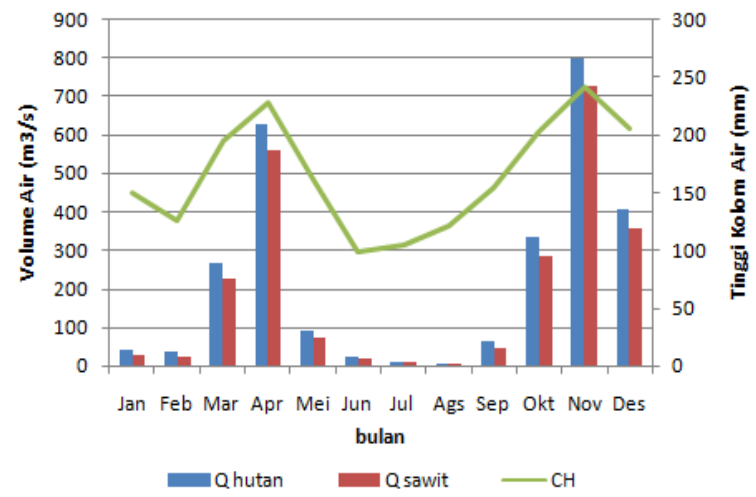

Gambar 5 Perbandingan debit antara sebelum dan sesudah ada perkebunan kelapa sawit.

Berdasarkan hasil analisis yang dilakukan, besarnya debit estimasi hasil perhitungan yang terjadi di Kecamatan Dayun sebelum ada perkebunan kelapa sawit adalah sebesar $2708 \mathrm{~m}^{3} / \mathrm{s}$ dan sesudah ada perkebunan kelapa sawit adalah sebesar $2359 \mathrm{~m}^{3} / \mathrm{s}$. Dari hasil analisis ini terjadi penurunan debit yang mengindikasikan adanya penurunan ketersediaan air di wilayah Kecamatan Dayun sebesar $349 \mathrm{~m}^{3} / \mathrm{s}$ per tahun.

\section{Analisis Ekonomi Lingkungan Tanaman Kelapa Sawit}

Pesatnya penambahan luas areal kelapa sawit didorong oleh tingginya kebutuhan produk kelapa sawit yang berupa minyak sawit terutama untuk penyiapan makanan (Mukherjee et al 2009). Penambahan luas ini akan berdampak pada status lingkungan dan perlu diestimasi nilai ekonomi lingkungannya. Salah satu metode yang umum digunakan adalah Contingent Valuation Method (CVM) dan alat analisisnya berupa kuisioner. Responden adalah masyarakat yang tinggal di sekitar perkebunan kelapa sawit. Sampel diambil di Desa Sawit Permai, dengan jumlah 200 KK dari $1034 \mathrm{KK}$ yang ada di desa ini.

\section{Karakteristik Umum Dan Kondisi Sosial Ekonomi Responden}

Karakteristik umum dan kondisi sosial ekonomi responden yang tinggal di sekitar perkebunan kelapa sawit di Desa Sawit Permai dapat dilihat pada Gambar 6. Umur responden berkisar antara 37 - 59 tahun atau rata-rata 50 tahun. Secara umum, pekerjaan responden tersebut adalah petani kelapa sawit, namun, sebanyak $27 \%$ merupakan wiraswasta. Tingkat pendidikan responden adalah 
SD $29 \%$, SMP 38,5\%, SMA 28,5\%, dan Sarjana 4 $\%$. Pendapatan responden berkisar antara $\mathrm{Rp}$ 4.500.000 dan $\mathrm{Rp}$ 1.500.000 sedangkan rata-ratanya dalam sebulan sebesar $\operatorname{Rp}$ 3.080.500. Sebanyak $67,5 \%$ responden menyatakan bahwa perkembangan perkebunan kelapa sawit di wilayah ini sangat berkembang; $31,5 \%$ menyatakan cukup berkembang; dan $1 \%$ menyatakan tidak berkembang secara baik.

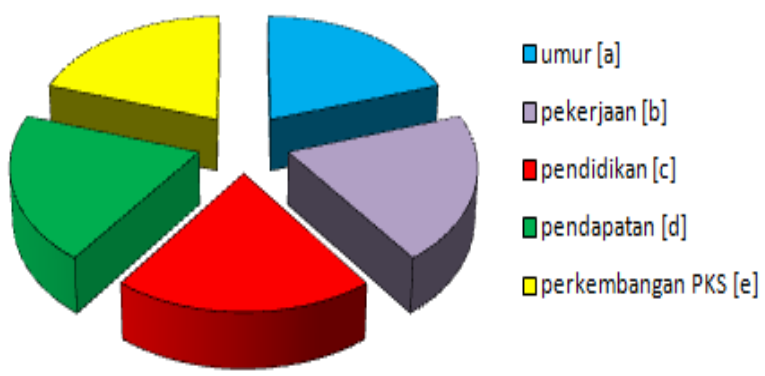

Gambar 6 Kondisi umum sosial ekonomi responden.

\section{Nilai Ekonomi Perkebunan Kelapa Sawit}

Nilai ekonomi perkebunan kelapa sawit dapat dilihat dari dua hal yaitu biaya pemeliharaan tetap per bulan dan Jasa buruh dalam pemanenan. Biaya tetap berupa pupuk dan pembayaran buruh waktu pemanenan, sedangkan biaya jasa mencakup jasa buruh waktu pemanenan TBS (79,5\% responden) dan upah yang dikeluarkan adalah sebesar $10 \%$ dari harga TBS.

\section{Nilai Lingkungan Tanaman Kelapa Sawit}

Dampak lingkungan yang dirasakan oleh responden yang tinggal di sekitar perkebunan akibat keberadaan perkebunan kelapa sawit dapat dilihat pada Gambar 7.

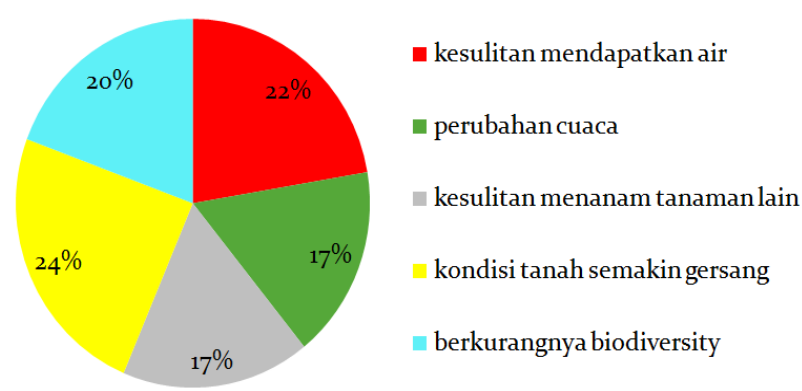

Gambar 7 Dampak lingkungan perkebunan kelapa sawit menurut responden.

Dari total responden, 22\% menyatakan bahwa sejak ada perkebunan kelapa sawit kondisi ketersediaan air semakin menurun dan terjadi kekurangan air pada saat musim kemarau, dan suhu udara semakin meningkat (17\% responden). Kondisi tanah sejak ditanami tanaman kelapa sawit menjadi tandus dan gersang (24\% responden), dan kehadiran perkebunan ini telah menghilangkan beberapa spesies baik flora maupun fauna yang ada di wilayah tersebut (20\% responden). Sebanyak $17 \%$ dari responden memberikan pendapat bahwa sejak ada perkebunan kelapa sawit mengalami kesulitan untuk menanam jenis tanaman lain, terutama jenis tanaman pangan.

\section{Estimasi Nilai Lingkungan Perkebunan Kelapa Sawit}

Nilai ekonomi lingkungan perkebunan kelapa sawit didekati sebagai dampak langsung yang diterima oleh masyarakat sekitar perkebunan akibat ada perkebunan kelapa sawit. Nilai lingkungan perkebunan kelapa sawit akan terasa pada saat musim kemarau yaitu terjadi perbedaan jumlah defisit air antara sebelum dan sesudah adanya perkebunan yaitu sebesar $5 \mathrm{~mm}$ yang merupakan kumulatif dari tiga bulan (JJA).

Berdasarkan data yang diperoleh dari PDAM Kab. Siak, rata-rata harga air per liter mencapai Rp 150. Nilai lingkungan yang dihasilkan adalah sebesar Rp 7.500.000. Nilai pendapatan petani sawit selama tiga bulan secara rata-rata adalah sebesar Rp 9.241.500. Nilai pendapatan petani sawit kemudian diasumsikan sebagai nilai ekonomi perkebunan kelapa sawit. Pada saat musim kemarau, perkebunan kelapa sawit merugikan terhadap lahan karena besarnya kebutuhan air perkebunan kelapa sawit menyebabkan peningkatan nilai defisit air namun pada saat musim penghujan, perkebunan kelapa sawit akan menguntungkan karena dapat mengurangi resiko banjir yang terjadi di wilayah setempat. Namun demikian, ada kemungkinan bencana banjir terjadi bukan di wilayah kecamatan ini melainkan di kecamatan lain yang topografinya lebih rendah dari kecamatan Dayun, namun, hal ini masih membutuhkan penelitian lebih lanjut untuk membuktikan kebenarannya.

Untuk memperbaiki dan mengantisipasi masalah kekurangan ketersediaan air di wilayah ini, maka diperlukan program konservasi air secara baik serta alokasi sumberdaya air berdasarkan kebutuhan yang ada. Upaya konservasi yang dapat dilakukan adalah peremajaan kembali hutan alam sebagai media konservasi alami. Sebanyak $73 \%$ dari total responden setuju dengan program peremajaan hutan di wilayah ini. Namun, sebanyak $27 \%$ responden tidak setuju dengan program peremajaan hutan di wilayah ini. Alasannya adalah hutan dalam fungsinya tidak mampu menambah nilai pendapatan dari masyarakat sekitar, perkebunan kelapa sawit memberikan nilai ekonomi yang lebih tinggi dibandingkan dengan nilai ekonomi yang dihasilkan dari hutan, membuka hutan berarti menambah lapangan pekerjaan dan penghasilan, sedangkan 
meremajakan hutan berarti berkurangnya lapangan perkerjaan yang ada.

\section{Analisis WTP Program Konservasi Sumberdaya Air}

a. Harga Bayangan Kerusakan Lingkungan

Kerusakan lingkungan akibat perkebunan kelapa sawit yang dirasakan oleh responden berdasarkan kuisioner diantaranya adalah kesulitan mendapatkan air. Hasil analisis CVM menyebutkan bahwa dalam waktu 6 tahun, sedikitnya penduduk sekitar melakukan pendalaman sumur untuk mendapatkan air guna memenuhi kebutuhan air untuk keperluan domestik. Berdasarkan hasil kajian ini nilai air yang hilang apabila terjadi peningkatan luas perkebunan kelapa sawit seluas satu hektar adalah sebesar Rp 100.500.000 per tahun atau setara dengan $\mathrm{Rp}$ 8.375 .000 per bulan atau Rp $8.100 / \mathrm{KK} / \mathrm{ha} /$ bulan. Bentuk kerugian lain selain nilai air adalah limbah sawit dan jumlah limbah ini akan semakin meningkat seiring dengan bertambah luasnya areal perkebunan. Teknik penanganan limbah yang saat sekarang diterapkan yaitu pembakaran limbah (waste incineration) dinilai tidak efisien dan menimbulkan masalah lingkungan (Yang et al 2006)

\section{b. Rata-Rata WTP Penduduk Desa Sawit Permai}

Sebanyak $73 \%$ dari responden setuju dengan program konservasi sumberdaya air di wilayah ini. Dukungan dan keikutsertaan masyarakat dalam upaya pengelolaan sumberdaya air di wilayah ini terlihat dari keinginan membayar (Willingness To Pays) untuk program ini, dan dapat ditentukan melalui contingen valuation method.

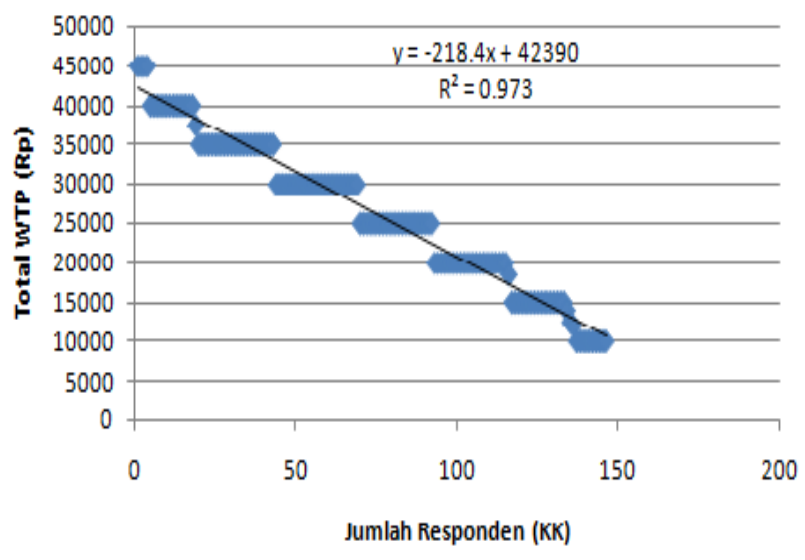

Gambar 8 Hubungan antara WTP dengan jumlah responden.

Hubungan antara total WTP dengan jumlah KK yang sanggup membayar WTP dapat dilihat pada Gambar 8. Hasil analisis menunjukkan bahwa nilai rata-rata WTP masyarakat Desa Sawit Permai untuk program reboisasi hutan sebesar Rp 26.400, dengan nilai WTP maksimum sebesar Rp 45.000 dan minimum Rp 5.000.

\section{c. Menetapkan bid curve}

Bid curve merupakan hubungan antara nilai riil total kerusakan lingkungan yang harus dibayarkan oleh setiap KK dengan total kemampuan membayar (WTP) dari setiap KK. Hubungan antara nilai riil total kerusakan lingkungan dengan kemampuan membayar dari setiap KK di Desa Sawit Permai terlihat pada Gambar 9.

Wilayah II merupakan wilayah total kerugian yang seharusnya dibayar oleh setiap KK, sedangkan wilayah I merupakan wilayah kemampuan yang mampu dibayar oleh setiap KK di Desa Sawit Permai (Gambar 9). Total kerusakan lingkungan yang seharusnya dibayar oleh penduduk di desa sawit permai adalah sebesar Rp 8.375.000/ha/bulan.

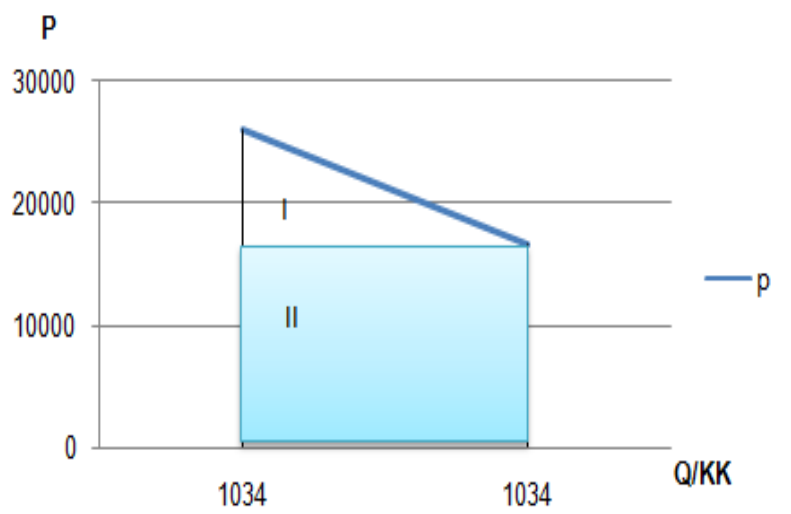

Gambar 9 Bid curve WTP masyarakat Desa Sawit Permai.

Kemampuan penduduk Desa Sawit Permai untuk membayar kerusakan lingkungan ini adalah sebesar Rp 27.300.000/ha/bulan. Dengan demikian didapatkan nilai surplus konsumen penduduk untuk program konservasi sumberdaya air sebesar Rp 18.850.000/ha/bulan. Nilai surplus konsumen ini menunjukan nilai manfaat ekonomi dari program konservasi sumberdaya air yang di inginkan oleh penduduk di desa Sawit Permai Kecamatan Dayun Kabupaten Siak.

\section{d. Agregat data}

Data yang diagregatkan merupakan data hasil kuisioner mengenai jumlah WTP rata-rata yang sanggup dibayarkan oleh setiap KK untuk program konservasi sumberdaya air di wilayah penelitian (Tabel 1).

Berdasarkan Tabel 1, nilai ekonomi program konservasi sumberdaya air yang diberikan oleh penduduk Desa Sawit Permai merupakan hasil perkalian antara rata-rata WTP dengan jumlah KK yang ada di desa tersebut. 
Tabel 1. Rata-rata WTP yang sanggup dibayar oleh responden

\begin{tabular}{|ccccc|}
\hline WTP & Rata-rata & Responden & \% & Nilai \\
\hline $5000-10000$ & 7500 & 10 & 6.8 & 75000 \\
$10001-15000$ & 12500.5 & 20 & 13.7 & 250010 \\
$15001-20000$ & 17500.5 & 24 & 16.4 & 420012 \\
$20001-25000$ & 22500.5 & 23 & 15.8 & 517511.5 \\
$25001-30000$ & 27500.5 & 26 & 17.8 & 715013 \\
$30001-35000$ & 32500.5 & 24 & 16.4 & 780012 \\
$35001-40000$ & 37500.5 & 15 & 10.3 & 562507.5 \\
$40001-45000$ & 42500.5 & 4 & 2.7 & 170002 \\
& & 146 & & 3490068 \\
\hline
\end{tabular}

Nilai ekonomi perbaikan lingkungan berupa program reboisasi dari penduduk di Desa Sawit Permai adalah sebesar Rp 3.500.000/ha/bulan. Nilai ekonomi program konservasi sumberdaya air memberikan nilai manfaat ekonomi sebesar $\mathrm{Rp}$ $18.850 .000 /$ ha/bulan.

\section{KESIMPULAN}

Neraca air umum di wilayah Kecamatan Dayun menunjukkan adanya tiga bulan defisit yaitu bulan JJA sedangkan sembilan bulan yang lain curah hujannya relatif tinggi. Puncak hujan terjadi pada bulan April dan bulan November (227 dan $241 \mathrm{~mm}$ ), dan curah hujan tahunan $1989 \mathrm{~mm}$. Dan ini sejalan dengan hasil analisis neraca air lahan yang juga memberikan informasi periode defisit di Kecamatan Dayun terjadi pada bulan JJA . Defisit air pada ketiga bulan tersebut secara kumulatif mencapai 22 $\mathrm{mm}$.

Perbedaan landcover antara sebelum dan sesudah adanya perkebunan kelapa sawit menunjukkan adanya penurunan nilai surplus air sebesar $50 \mathrm{~mm}$ per tahun. Penurunan surplus akan mempengaruhi debit yang terjadi. Debit sebelum ada perkebunan kelapa sawit adalah sebesar $2708 \mathrm{~m}^{3} / \mathrm{s}$ tetapi sesudah ada perkebunan turun menjadi 2359 $\mathrm{m}^{3} / \mathrm{s}$. Alih fungsi lahan dari hutan ke tanaman monokultur seperti perkebunan kelapa sawit berpengaruh terhadap peningkatan limpasan langsung (run off). Nilai run off untuk landcover hutan adalah sebesar $16 \mathrm{~mm}$, sedangkan untuk perkebunan sawit adalah $200 \mathrm{~mm}$. Kebutuhan air tanaman kelapa sawit yang ada di Kecamatan Dayun adalah 42.728 liter/ha/hari. Berdasarkan hasil analisis debit estimasi, terjadi penurunan debit yang mengindikasikan penurunan ketersediaan air di wilayah Kecamatan Dayun sebesar $349 \mathrm{~m}^{3} / \mathrm{s}$ per tahun.

Estimasi nilai lingkungan untuk perkebunan kelapa sawit dilihat dari segi konsumsi sumberdaya air adalah sebesar Rp 2.339.331.300/ha/tahun sedangkan pendapatan rata-rata petani dari lahan seluas satu hektar per tahun hanya sebesar Rp 1.124.382.500. Dari hasil ini dapat dilihat bahwa nilai lingkungan perkebunan kelapa sawit lebih besar dibandingkan dengan nilai ekonominya. Nilai WTP rata-rata masyarakat untuk program reboisasi adalah Rp 26.400, dengan nilai WTP maksimum sebesar Rp 45.000 dan WTP minimum Rp 5.000. Total kerusakan lingkungan yang seharusnya dibayar oleh penduduk di Desa Sawit Permai adalah sebesar Rp 8.375.000/ha/bulan. Kemampuan penduduk Desa Sawit Permai untuk membayar kerusakan lingkungan ini adalah sebesar Rp 27.300.000/ha/bulan. Dengan demikian didapatkan nilai surplus konsumen penduduk (Desa Sawit Permai, Kecamatan Dayun, Kabupaten Siak) untuk program konservasi sumberdaya air sebesar Rp 18.850.000/ha/bulan.

\section{DAFTAR PUSTAKA}

Adi S. 2007. Pola Pengelolaan Sumberdaya Air DAS Siak, Riau. Alami 12(1):34-43

[BPS Kab. Siak] Badan Pusat Statistik Kabupaten Siak. 2008. Siak Dalam Angka. Siak: Badan Pusat Statistik Kabupaten Siak.

Dinas Kehutanan dan Perkebunan Kabupaten Siak. 2009. Luas area perkebunan kelapa sawit di Kabupaten Siak. Siak.

Doorenbos R J dan Pruit W O. 1976. Agrometeorological Field Station Irrigation and Drainage. Paper no 27. Rome: FAO.

Fitzherbert EB, Struebig MJ, Morel A, Danielsen F, Brül CA, Donald PF dan Phalan B. 2008. How will oil palm expansion affect biodiversity? Trends in Ecology and Evolution 23(10): 538-545.

Hariadi. 2006. Kajian Potensi Air Sungai Siak Untuk Penyediaan Air Baku di Kabupaten Siak Propinsi Riau [Tesis]. Bandung: Teknik Lingkungan, Institut Teknologi Bandung.

Mock F J. 1973. Land Capabilty Appraisal Indonesia, Water Availability Appraisal. UNDP-FAO

Mukherjee S dan Mitra A. 2009. Health Effects of Palm Oil. J Hum Ecol 26(3): 197-203. 
Murtilaksono K, Siregar HH dan Darmosarkoro W. 2007. Model Neraca Air di Perkebunan Kelapa Sawit. J Penelitian Kelapa Sawit 15(1): 21-35.

Darmosarkoro W, Sutarta ES, Siregar HH dan Hidayat Y. 2009. Upaya Peningkatan Produksi Kelapa Sawit Melalui Penerapan Teknik Konservasi Tanah dan Air. J Tanah Trop 14(2): 135-142.
Nasrul B dan Anom E. 2008. Masukan Teknologi Tinggi untuk Meningkatkan Kelas Kesesuaian Lahan Kelapa Sawit (Studi Kasus: PT Teso Indah). Sagu 7(2): 19-24.

Yang H, Yan R, Liang DT, Chen H dan Zheng C. 2006. Pyrolysis of Palm Oil Wastes for Biofuel Production. As J Energy Env 7(02): 315-323. 